\title{
STUDIES ON SOME HONEYBEE RACES (APIS MELLIFERA L.) IN EGYPT
}

FATHY, H. M. ${ }^{1}$, S. S. AWADALLA ${ }^{1}$, S. M. ABOU- LILA ${ }^{2}$, A. A.TAHA ${ }^{2}$

1- Economic Entomology Dept., Faculty Of Agriculture, Mansoura University, Egypt. 2- Beekeeping Dept., Plant Protection Research Institute, ARC, Egypt.

(Manuscript received 27 April 2011)

\begin{abstract}
The study was carried out to evaluate the efficiency of Carniolan; Italian and F1 Italian in the production of sealed brood (worker and drone), queen cells, stored pollen and honey production. Three peaks of worker brood production had happened during the whole year. The first, the second and the third peaks were in February, May and August, respectively. It was obvious that Italian race produced the lowest number of drone brood during the whole year. In contrast, Carniolan race was outstanding in drone brood production. February and May produced the largest area of drone brood in the three races during the whole year. Italian race was the inferior in queen cells production. Meanwhile, Carniolan race was superior. Conversely, insignificant differences among the three races in queen cells production were observed. Italian race was outstanding in stored pollen activity, contrary to F1 Italian hybrid which was the lowest races in production. As an illustration, insignificant differences between Italian and Carniolan races were noticed. It was obvious that Carniolan and Italian races produced the highest amounts of honey.

Key words: honeybee, brood rearing, stored pollen, queen cells, honey production.
\end{abstract}

\section{INTRODUCTION}

The study was carrying out to manifest the efficiency of Carniolan, $A$. mellifera carnica, Italian, $A$. mellifera ligustica, and F1 Italian Hybrid), in the production of worker and drone brood and the adaptation under Egypt environmental conditions. Many authors handled with the important of studying the biological aspects (worker and drone brood rearing, queen cells number; stored pollen activity and honey production) Brar et. al., 1992a، b; Al-Humayari et al., 1999; El-Waseef, 2002. Cobey, 1992 showed that brood rearing of Carniolan race has been found directly related to the availability of pollen which can pose a problem, and the brood nest is compact and uniform. While, the brood development of Italian bees starts in early spring which affords them a large populations that is maintained until fall. On the other hand, F1 Italian honeybee performed larger areas of worker brood, greater amounts of propolis, stored pollen areas and cotton honey yields than F1 Carniolan honeybee, Serag El-Deen, 2004. In this investigation of the different races (Carniolan, A. mellifera carnica, Italian, A. mellifera ligustica, and F1 Italian Hybrid), the following 
points were conducted: worker brood rearing activity, drone brood, queen cells, stored pollen and honey production activity.

\section{MATERIALS AND METHODS}

The experiments in this study were carried out at El-Baydaa village, ElSenbellaween, Dakahlia Governorate, for one year, beginning in September 2004 and ending in August 2005. Nine honeybee colonies, three pure Carniolan colonies, three pure Italian colonies and three F1 Italian Hybrid colonies were used. Studies were carried out to investigate the amounts of workers and drones reared in colonies of the Carniolan, Italian and F1 Italian, in addition to the number of queen cells. The investigation of brood rearing activity in the different races to differentiate between races as far as the important factor concerning honey production is concerned.

\section{Estimation of worker and drone brood rearing:}

To estimating the rate of worker and drone brood activity for each race during a whole year, a typical Langstroth frame (19 inch in length and seven inch in width) was divided into 133 square inches by means of wire. This frame was laid against any comb in which it was desired to count the number of sealed brood (Fig. 1).

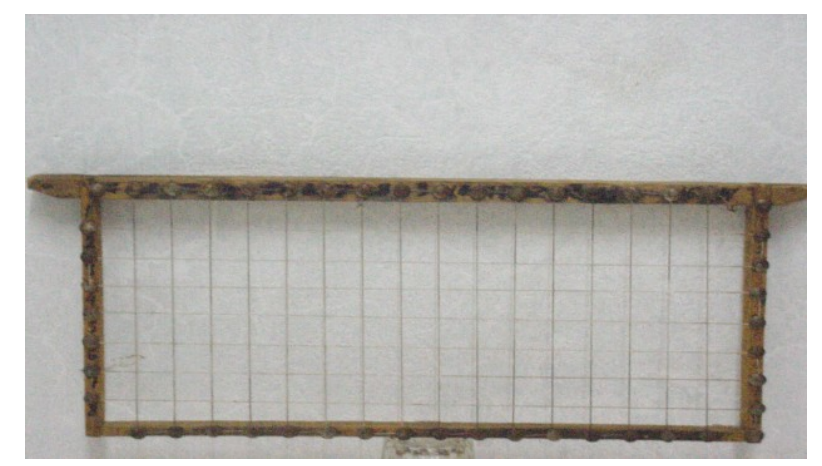

(Fig. 1). Brood measurement frame

The counts were made at intervals of 12 days; this method of counting was according to Al-Tikrity et. al. (1971). The number of worker sealed brood cells was calculated by multiplying the number of squares by 25 , which proved to be the number of worker cells per square inch in the three races. The number of drone sealed brood cells per square inch was counted, and then the number of square inches was converted into number of cells by multiplying the number of squares by 16 , which proved to be the number of drone cells per square inch in the three races. 


\section{Queen cells production:}

Tendency of swarming is much correlated to the number of drones and queen reared during the swarming season. For queen cells, total number of queen cells built during a year was counted at intervals of ten days to give an idea about the intensity of swarming and its time. Average temperature and relative humidity were monthly recorded.

\section{Estimation of stored pollen:}

The same previous method of brood counting was used at 12 days intervals, to count the number of square inches of pollen grains stored by the field workers in different races. Ten samples of pollen grains were taken randomly from stored pollen in colonies, each sample (containing pollen of 20 cells) was weighed and the average weight of pollen cell was estimated. The weight of one stored pollen cell of Carniolan, F1 Italian and Italian races were $0.1459,0.117$ and $0.0944 \mathrm{gm} . /$ cell, respectively.

\section{Estimation of honey production:}

Clover honey yield in different colonies races was estimated by measuring the open and sealed honey areas in June and transformed into weight using the following formula according to Shawer et. al.(1986).

$$
\text { Honey yield in } \mathrm{kg}=\frac{\text { Area of honey }(\text { square inches }) \times 10.64 \mathrm{~g}}{1000}
$$

where: $10.64=$ Amount in grams of honey in one square inch, based on averages calculated from unsealed and sealed honey from combs of different thickness.

\section{RESULTS AND DISCUSSION}

\section{Worker brood rearing activity:}

Table (1) and (2) recorded the monthly, seasonally and total counts of worker sealed brood cells for the three races. Data showed that brood rearing level in the three races fluctuated slightly from one month to another within the season, but differed greatly between seasons. The brood rearing activity started slowly by the beginning of February in the three races; then egg laying capacity increased sharply by the beginning of spring reaching its first peak during March. The Italian bees showed the highest level followed by the Carniolan bees during the same period. The peak of the F1 Italian bees was the lowest in egg laying capacity during winter. From Table (2), analysis of variance showed that there is a significant difference between the Italian and F1 Italian races in egg production during spring. But, insignificant difference occurred between Carniolan and F1 Italian in egg laying capacity during spring. At the beginning of summer, a second major peak of egg laying was recorded during the blooming season of clover for the Italian race, since the queen continued 
egg production. For the other two races, queens declined slightly in egg yield, especially than the Carniolan race. During summer, other three peaks were recorded. The highest peak was of the Carniolan and the Italian

Table 1 . Monthly and seasonal average of worker sealed brood sq. in./colony during

\begin{tabular}{|l|l|l|l|}
\hline \multicolumn{3}{|l}{$2004 / 2005}$. & \multicolumn{2}{l|}{ Carniolan } & F1 Italian \\
\cline { 2 - 4 } Months & Races & 220 & 295 \\
Sep. 2004 & 552 & 369 & 472 \\
Oct. & 708 & 147 & 126 \\
Nov. & 210 & $736(16.7 \%)$ & $893(23.6 \%)$ \\
\hline Autumn & $1470(24.1 \%)$ & 167 & 168 \\
\hline Dec. & 352 & 123 & 102 \\
Jan. 2005 & 284 & 231 & 170 \\
Feb. & 421 & $521(11.9 \%)$ & $440(11.5 \%)$ \\
\hline Winter & $1057(17.3 \%)$ & 704 & 549 \\
\hline Mar. & 696 & 262 & 180 \\
Apr. & 451 & 624 & 565 \\
May & 794 & $1590(36.2 \%)$ & $1294(34.2 \%)$ \\
\hline Spring & $1941(31.8 \%)$ & 478 & 333 \\
\hline Jun. & 457 & 294 & 213 \\
Jul. & 283 & 776 & 616 \\
\hline Aug. & 893 & $1548(35.2 \%)$ & $1162(30.7 \%)$ \\
\hline Summer & $1633(26.8 \%)$ & 4395 & 3789 \\
\hline Average/year & 6101 & & \\
\hline & & & \\
\hline
\end{tabular}

bees. The lowest peak was that of the F1 Italian. However, analysis of variance did not show any differences among the three races. During autumn, brood rearing continued in a high level, especially for the Italian colonies. Analysis of variance indicated insignificant difference in egg laying capacity between the Carniolan and F1 Italian. Significant difference occurred between Italian race and both of (Carniolan and F1 Italian races), as well as between Italian and F1 Italian. In winter, the lowest level of egg production occurred for the three races, this also mentioned by Yakoub, 1998. Insignificant difference between the F1 Italian and Carniolan existed; but, significant difference between the Italian and F1 Italian occurred, as well as between Italian and Carniolan races. For the whole year, significant difference between the 
Italian and Carniolan races was recorded. But, insignificant difference between the Carniolan and F1 Italian existed.

Table 2 . Statistical analysis of worker production (sq. in.) in the three races for the whole year and different seasons.

\begin{tabular}{|l|l|l|l|l|l|}
\hline \multicolumn{1}{|c|}{ Season } & Autumn & Winter & Spring & Summer & Total/ Year \\
\hline Italian & 1470 & 1057 & 1941 & 1633 & 6101 \\
\hline Carniolan & 736 & 521 & 1590 & 1548 & 4395 \\
\hline F1 Italian & 893 & 440 & 1294 & 1162 & 3789 \\
\hline L.S.D ${ }_{5 \%}$ & 378.41 & 110.27 & 422.44 & 516.79 & 703.71 \\
\hline F. Test & 1.39 ns & $12.3 * *$ & $0.78^{\mathrm{ns}}$ & $0.31^{\mathrm{ns}}$ & $1.86^{\mathrm{ns}}$ \\
\hline
\end{tabular}

Any two means not connected by the same line are significantly different at $\mathrm{P}=0.05$

\section{Drone brood rearing activity:}

Tables ( 3 and 4 ) showed that the statistical analysis of drone production in the three races for the whole year. Insignificant difference among the three races was recorded during winter season. Also, insignificant difference between Italian and Carniolan races was observed in autumn and summer seasons. Meanwhile, there was a significant difference between F1 Italian and both of (Italian and Carniolan races) in autumn and summer seasons during the whole year. In spring, insignificant difference between Italian and F1 Italian and between Carniolan and F1 Italian was occurred. For the whole year, Italian race was significantly inferior to the other two races. This data is in agreement with, Rock, 1977 and Szabo, 1995. 
Table 3. Monthly and seasonal average of drone sealed brood (sq. in.)/ colony during 2004/2005.

\begin{tabular}{|l|l|l|l|}
\hline \multirow{2}{*}{ Months } & \multicolumn{3}{|c|}{ Races } \\
\cline { 2 - 4 } & Italian & Carniolan & F1 Italian \\
\hline Sep. 2004 & 0 & 0 & 0 \\
Oct. & 0 & 0 & 9 \\
Nov. & 1 & 6 & 5 \\
\hline Autumn & $1(3.0 \%)$ & $6(5.9 \%)$ & $14(14.7 \%)$ \\
\hline Dec. & 3 & 6 & 0 \\
Jan. 2005 & 1 & 3 & 5 \\
Feb. & 6 & 26 & 20 \\
\hline Winter & $10(30.3 \%)$ & $35(34.3 \%)$ & $25(26.3 \%)$ \\
\hline Mar. & 1 & 4 & 8 \\
Apr. & 7 & 20 & 2 \\
May & 13 & 36 & 43 \\
\hline Spring & $21(63.7 \%)$ & $60(58.8 \%)$ & $53(55.8 \%)$ \\
\hline Jun. & 1 & 1 & 0 \\
Jul. & 0 & 0 & 1 \\
Aug. & 0 & 0 & 2 \\
\hline Summer & $1(3.0 \%)$ & $1(1.0 \%)$ & $3(3.2 \%)$ \\
\hline Average/year & 33 & 102 & 95 \\
\hline
\end{tabular}

Whereas, insignificant differences between Carniolan and F1 Italian races were noticed. The mounts of drone brood fluctuate more than worker brood. So, it seems that drone production is sensitive to many factors, while it is generally accepted that a reduction in queen substance in the hive is likely to cause the initiation of drone and queen rearing and subsequent swarming (El-Sheriff et. al.(1994) Shoreit et. al.(2002) Serag El-Dien (2004). 
Table 4. Statistical analysis of drone production in the three races for the whole year and different seasons.

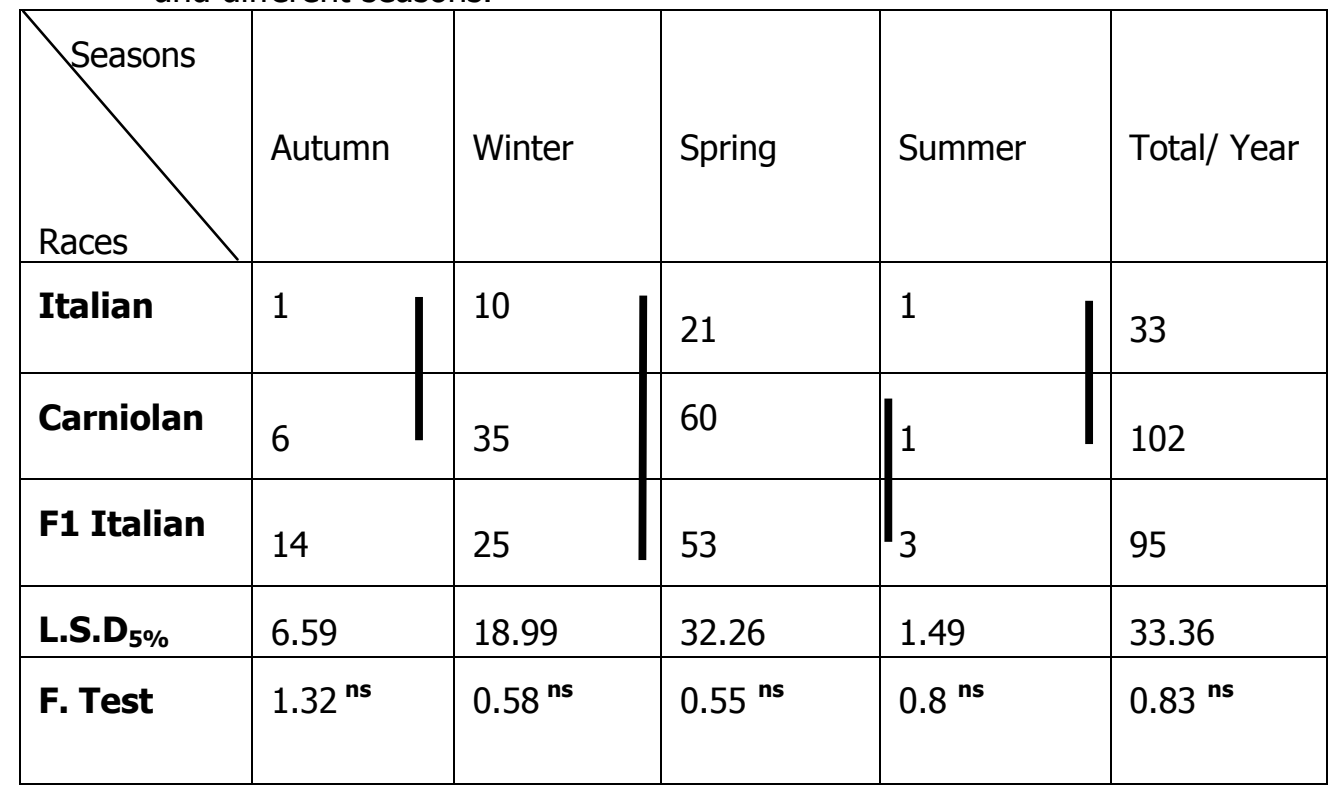

Any two means not connected by the same line are significantly different at $P=0.05$

\section{Queen cells:}

From Table (5) it is observed that both the Carniolan and the F1 Italian colonies produced large numbers of queen cells during the year, however, the Carniolan colonies exceed the F1 Italian colonies. For the Italian colonies, only one cell was built during July. For the Carniolan colonies, the total queen cells built during the year was about 78 per colony, while Italian colonies built 17 queen cells/ year. For the F1 Italian colonies, the total queen cells built during the year was about 45 cells per colony. It was observed that $53 \%$ and $46.7 \%$ of the total number of queen cells was in spring season in both of Italian and F1 Italian race, respectively. Table ( 6 ) showed that a significant difference was observed in queen cells production in the three races during the whole year. Carniolan race significantly produced the highest number of queen cells. 
Table 5. Monthly and seasonal average number of queen cells/colony during 2004/2005.

\begin{tabular}{|c|c|c|c|}
\hline \multirow{2}{*}{ Months } & \multicolumn{3}{|c|}{ Races } \\
\cline { 2 - 4 } & Italian & Carniolan & F1 Italian \\
\hline Sep. 2004 & 1 & 12 & 0 \\
Oct. & 1 & 5 & 2 \\
Nov. & 1 & 18 & 0 \\
\hline Autumn & $3(17.6 \%)$ & $35(44.9 \%)$ & $2(4.4 \%)$ \\
\hline Dec. & 2 & 2 & 5 \\
Jan. 2005 & 0 & 1 & 0 \\
Feb. & 0 & 2 & 9 \\
\hline Winter & $2(11.8 \%)$ & $5(6.4 \%)$ & $14(31.1 \%)$ \\
\hline Mar. & 1 & 6 & 7 \\
\hline Apr. & 2 & 4 & 5 \\
\hline May & 6 & 8 & 9 \\
\hline Spring & $9(53.0 \%)$ & $18(23.1 \%)$ & $21(46.7 \%)$ \\
\hline Jun. & 0 & 0 & 0 \\
\hline Jul. & 1 & 16 & 6 \\
Aug. & 2 & 4 & 2 \\
\hline & $3(17.6 \%)$ & $20(25.6 \%)$ & 45 \\
\hline Average/year & 17 & 78 & \\
\hline
\end{tabular}

Table 6 . Statistical analysis of queen cells produced in the three races for the whole year and different seasons.

\begin{tabular}{|c|c|c|c|c|c|}
\hline Races & Autumn & Winter & Spring & Summer & Total/ Year \\
\hline Carniolan & 35 & 5 & $18 \mathbf{a}$ & 20 & 78 \\
\hline Italian & 3 & 2 & 9 b & 3 & 17 \\
\hline F1 Italian & 2 & 14 & $21 \mathbf{a}$ & 8 & 45 \\
\hline L.S.D $5 \%$ & 7.62 & 5.41 & 4.47 & 10.3 & 13.93 \\
\hline F. Test & $8.07 *$ & $1.77^{\mathrm{ns}}$ & $2.6^{\mathrm{ns}}$ & $0.96^{\mathrm{ns}}$ & $3.07^{\text {ns }}$ \\
\hline
\end{tabular}

Any two means not connected by the same line are significantly different at $\mathrm{P}=0.05$ 
Insignificant difference was found between Italian and F1 Italian race in autumn and summer seasons. Also, insignificant difference was occurred between Italian and Carniolan race in winter. Moreover, insignificant difference was noticed between Carniolan and F1 Italian in spring. To illustrate, Carniolan race was significantly superior in autumn and summer. Insignificant difference was noticed between Italian and F1 Italian in queen cells produced during the whole year.

\section{Stored pollen activity:}

As shown in Table (7), Italian race was the superior of all the races in stored pollen areas during the whole year with an average 1354 sq. in./ colony/ year ( 3195 $\mathrm{gm} /$ colony / year). While, F1 Italian was the inferior of the races in stored pollen areas with an average $900 \mathrm{sq}$. in. / colony / year ( $2648 \mathrm{gm} /$ colony / year). The average of Carniolan race was 1217 sq. in. / colony / year, (4430 gm/ colony / year), respectively of stored pollen areas. The highest amount was recorded during spring with an average 574, 573 and 444 sq. in./ colony, representing 42.4, 47.1 and $49.4 \%$ for Italian, Carniolan and F1 Italian, respectively.

Table 7. Monthly average of stored pollen (sq. in.) and pollen weight gm / colony for the three studied races during 2004/2005.

\begin{tabular}{|c|c|c|c|c|c|c|c|c|c|c|}
\hline \multirow{2}{*}{\multicolumn{2}{|c|}{ Month }} & \multicolumn{3}{|c|}{ Av. Monthly (sq. in.) } & \multicolumn{3}{|c|}{ Av. Weight (gm) } & \multicolumn{3}{|c|}{$\%$} \\
\hline & & I & C & IH & I & C & IH & I & C & IH \\
\hline \multirow{4}{*}{ 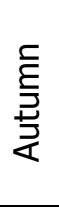 } & Sep. & 16 & 6 & 6 & 38 & 22 & 18 & 1.2 & 0.5 & 0.6 \\
\hline & Oct. & 122 & 106 & 82 & 288 & 386 & 241 & 9.1 & 8.7 & 9 \\
\hline & Nov. & 59 & 75 & 33 & 139 & 273 & 97 & 4.3 & 6.2 & 3.7 \\
\hline & Total & 197 & 187 & 121 & 465 & 681 & 356 & 14.6 & 15.4 & 13.3 \\
\hline \multirow{4}{*}{ 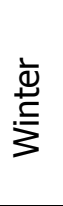 } & Dec. & 138 & 70 & 63 & 326 & 255 & 185 & 10.1 & 5.8 & 7 \\
\hline & Jan. & 92 & 134 & 88 & 217 & 488 & & 6. & 11 & 9.8 \\
\hline & Feb. & 123 & 91 & 68 & 290 & 331 & 200 & 9.1 & 7.5 & 7.6 \\
\hline & Total & 353 & 295 & 219 & 833 & 1074 & 644 & 26 & 24.3 & 24.4 \\
\hline \multirow{4}{*}{$\begin{array}{l}\text { श) } \\
\text { जे } \\
\text { जे }\end{array}$} & Mar. & 115 & 165 & 106 & 271 & 601 & 312 & 8.5 & 13.6 & 11.8 \\
\hline & Apr. & 65 & 77 & 51 & 153 & 280 & & 4. & 6. & 5.7 \\
\hline & May & 394 & 331 & 287 & 930 & 1205 & 844 & 29.1 & 27.2 & 31.9 \\
\hline & Total & 574 & 573 & 444 & 1354 & 2086 & 1306 & 42.4 & 47.1 & 49.4 \\
\hline \multirow{4}{*}{ 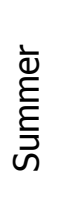 } & Jun. & 64 & 57 & 37 & 151 & 207 & 109 & 4.7 & 4.6 & 4.1 \\
\hline & Jul. & 44 & 17 & 24 & 104 & 62 & 71 & 3.3 & 1.4 & 2.7 \\
\hline & Aug. & 122 & 88 & 55 & 288 & 320 & 162 & 9 & 7.2 & 6.1 \\
\hline & Total & 230 & 162 & 116 & 543 & 589 & 342 & 17 & 13.2 & 12.9 \\
\hline \multicolumn{2}{|c|}{ Total / year } & 1354 & 1217 & 900 & 3195 & 4430 & 2648 & 100 & 100 & 100 \\
\hline
\end{tabular}

$\mathrm{I}=$ Italian

$\mathrm{C}=$ Carniolan $\quad \mathrm{IH}=\mathrm{F} 1$ Italian hybrid 
Carniolan race and F1 Italian were the lowest races in stored pollen area in Summer with an average 162 and 116 sq. in. / colony, representing 13.2 and $12.9 \%$, respectively. While Italian race was the lowest in Autumn with an average 197 sq. in. / colony, with percentage $14.6 \%$. It is clear obvious from Table (7) that May was the highest month of stored pollen areas for the three races during 2004/2005. Italian, Carniolan and F1 Italian averages were 394, 331 and 287 sq. in. / colony, with percentage 29.1, 27.2 and $31.9 \%$, respectively. On the other hand, September was the lowest month of stored pollen areas with an average 16, 6 and 6 sq. in. / colony, with percentage $1.2,0.5$ and $0.6 \%$ for Italian, Carniolan races and F1 Italian, respectively. Italian race was active in pollen storage in May, Dec., Feb., Aug., Oct. and Mar., with an average 394, 138, 123, 122, 122 and 115 sq. in. / colony, with an average weight 930, 326, 290, 288, 288 and 271 gms/ colony, respectively. While, Sept., Jul. and Nov. were the lowest months in stored pollen areas, with an average 16, 44 and 59 sq. in. / colony, with an average weight 38, 104 and 139 gms/ colony, respectively.

Table 8. Analysis of variance of stored pollen (sq. in. /colony) in different seasons in the three races during 2004/2005.

\begin{tabular}{|l|l|l|l|}
\hline Season & Italian & Carniolan & F1 Italian \\
\hline Autumn & $197 \mathrm{a}$ & $187 \mathrm{a}$ & $121 \mathrm{a}$ \\
\hline Winter & $353 \mathrm{c}$ & $295 \mathrm{a}$ & $219 \mathrm{a}$ \\
\hline Spring & $574 \mathrm{~b}$ & $573 \mathrm{~b}$ & $444 \mathrm{~b}$ \\
\hline Summer & $230 \mathrm{a}$ & $162 \mathrm{a}$ & $116 \mathrm{a}$ \\
\hline Total & 1354 & 1217 & 900 \\
\hline L.S.D. 5\% & 139.04 & 128.72 & 129.46 \\
\hline F. Test & $13.14^{* * *}$ & $18.70^{* * *}$ & $12.28^{* * *}$ \\
\hline
\end{tabular}

There are insignificant differences between the means with the same letters.

Regarding statistical analysis, Table (8) showed that there were insignificant differences between autumn, winter and summer seasons in stored pollen for Carniolan race, during the whole year. In contrast, there were highly significant differences between spring season and the other seasons (autumn, winter and summer) in stored pollen during 2004/2005. The same trend was observed for F1 Italian race in stored pollen. There was insignificant difference between autumn, winter and summer during the whole year. Highly significant differences were observed between spring season and the other ones (autumn, winter and summer) in stored pollen in F1 Italian race during the whole year. These fluctuations in stored pollen activities during the months of 2004/2005 may be attributed to the availability 
of pollen sources during months, colony strength, heredity behaviour and suitability of environmental conditions.

In general, there was a highly significant difference between spring seasons and (autumn, winter and summer) seasons in stored pollen for Italian, Carniolan and F1 Italian race during 2004/2005. There were insignificant differences between autumn and summer seasons in stored pollen for the three races during the whole year. From the above data, it could be concluded that Italian race was more active in stored pollen than both Carniolan and F1 Italian races under Dakahlia environmental conditions. These results agree with (El-Bassuny, 1989 and El-Hanafy, 1998).

\section{Honey production activity:}

Table (9) showed that the average yield was $9.06,8.85$ and $4.80 \mathrm{~kg} . /$ colony for Italian, Carniolan and F1 Italian, respectively. For statistical analysis there was insignificant difference between Italian and Carniolan races in honey production during the clover season. But, there was highly significant difference between both (Italian and Carniolan) and F1 Italian races.

Table 9. Statistical analysis of the honey production for the three races during the clover honey 2005.

\begin{tabular}{|l|l|l|}
\hline Race & $\mathrm{Kg}$ & Square inch \\
\hline Carniolan & $8.85 \pm 2.61$ & $833.8 \pm 243.76$ \\
Italian & $9.06 \pm 1.69$ & $855.0 \pm 161.71$ \\
F1 Italian & $4.80 \pm 1.45$ & $453.3 \pm 133.37$ \\
\hline L.S.D. 5\% & 2.34 & 228.41 \\
\hline
\end{tabular}

Any two means not connected by the same line are significantly different at the $5 \%$ level

\section{Relationships between different races:}

Table 10. Analysis of variance of the yearly average of some honey bee products in the three races during 2004/2005.

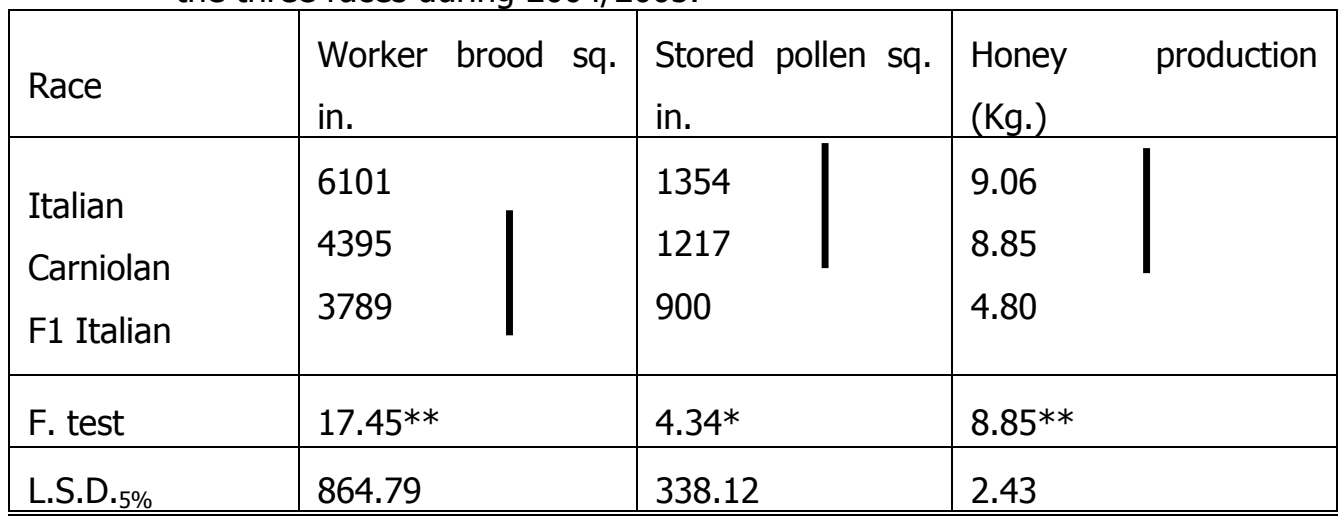

Any two means not connected by the same line are significantly different at the $5 \%$ level 
In conclusion, Table (10) showed that the relationships between different races and their secondary bee products. In relation to worker brood activity, it found that Italian race was significantly superior to both of (Carniolan and F1 Italian races) in worker brood in square inch during the whole year. Moreover, insignificant difference between Carniolan and F1 Italian races in worker brood was observed. On the other hand, insignificant difference between Italian and Carniolan races in stored pollen area was observed. Italian and Carniolan races were significantly outstanding. Equally, insignificant difference between Italian and Carniolan races in clover honey production per $\mathrm{Kg}$. was found. Italian and Carniolan races were significantly outstanding.

\section{REFERENCES}

1. Al-Humyari, A. A., M. E. El-Sherif and Kh. S. A. Naser. 1999. Brood rearing, food storage and worker longevity of Yemeni bee colonies and their Carniolan hybrid. J. Agric. Sci. Mansoura Univ., 24(3): 1345-1358.

2. Al-Tikrity, W. S., R. C. Hillmann, A. W. Benton and W. W. Clarke. 1971. A new instrument for brood measurement in a honey bee colony. Amer. Bee J., 111(4): $143-145$.

3. Brar, H. S., G. S. Gatoria and H. S. Jhajj, 1992a. Seasonal brood rearing of Apis mellifera Linn. under different agroclimatic regions of the Punjab. J. Insect Sci., 5(1): 27-29.

4. Brar, H. S., G. S. Gatoria and H. S. Jhajj. 1992b. Seasonal variations in honey stored by Apis mellifera Linn. Colonies in different agroclimatic regions of the Punjab. J. Insect Sci., 5(2): 141-143.

5. Cobey, S. 1992. The Carniolans Apis mellifera carnica. Amer. Bee J., 132(4): 246-248.

6. El-Bassuny, M. N. 1989. Studies on spread and distribution of pollen grains collected by honeybees with reference to their chemical composition. Ph.D. Thesis, Fac. Agric., El-Azhar. Univ., 200+4 pp.

7. El-Hanafy, R. E. 1998. studies on some honey bee races in Egypt. Ph. D. Thesis, Fac. Agric., Zagazig Univ. (Benha Branch), 141+7 pp.

8. El-Sheriff, M. E. , M. M. Mazeed and H. T. Abou El-Enain. 1994. Effect of pollen absence in honeybee colonies on drone and worker brood rearing activity. 5th Conf. Agric. Dev. Res., Fac. Agric., Ain Shams Univ., Cairo, Egypt, 2: 611-624. 
9. El-Waseef, R. A. 2002. Ecological and physiological studies on honeybee colonies under different environmental conditions. M. Sc. Thesis, Fac. Agric., Cairo Univ.

10. Rock, H. J. 1977. Variations in different strains of bees. Gleanings in Bee Culture, 105(7): 312-313.

11. Serag EI-Dien, F. Sh. 2004. Comparative study on some products on Italian and Carniolan Honeybee hybrids at Kafr EL-Sheikh Governorate. J. Agric. Sci. Mansoura Univ., 29 (1): 409-416.

12. Shawer, M. B., Z. Shenishen and N. M. El-Dakhakhni. 1986. Effect of colony strength activity and productivity of honey bee colonies. Bull. Soc. Ent. Egypt, 66(3): 65-73.

13. Shoreit, M. N., M. H. Hussein, M. O. M. Omar and M. F. Abdel- Rahman. 2002. Brood rearing of the honeybee colony individuals and their activities in Assiut region. Egypt. J. Agric. Res., 80(1): 83-103.

14. Szabo, T. I. 1995. The production of drone comb and drone brood in honey bee colonies. Amer. Bee. J., 135(9): 642-643.

15. Yakoub, W. A. 1998. Comparative studies on some honeybee races. M. Sc. Thesis, Fac. Agric., Alex. Univ., 122+6pp. 


\section{دراســات على بعض سـلالات نحسل العسل في مصـر (Apis mellifera L.)}

حسن محمد فتحى'، سمير صالح عوض الله'، سعد مصطفى أبو ليلة '،

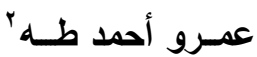

$$
\begin{aligned}
& \text { 1 - قسم الحشرات الاقتصادية- كلية الزراعة- جامعة الدنصورة- مصر. } \\
& \text { r- قسم بحوث النحل- معهد بحوث وقاية النباتات- مركز البحوث الزراعية- مصر. }
\end{aligned}
$$

أجريت هذه الدراسة بهدف تقييم كفاءة سلالة النحل الكرنيولى و الايطالى و الهجين أول

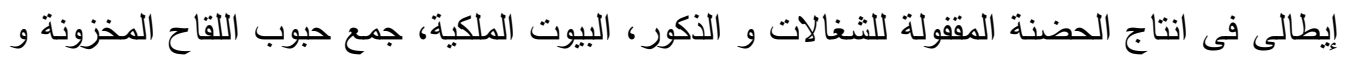

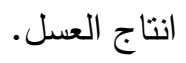

وجدت ثلاث ذروات فى نثاط تربية حضنة الثغالات خلال العام. الذروه الاولى كنت فى

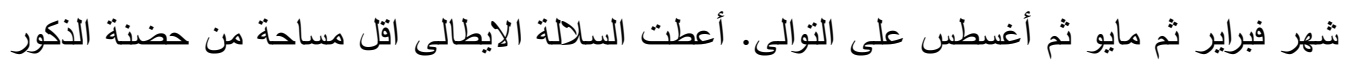

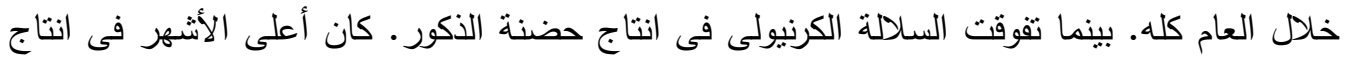

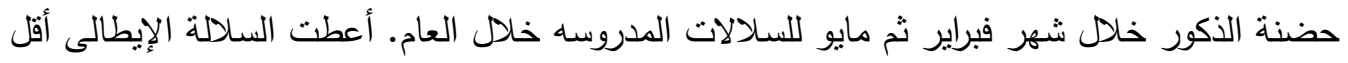

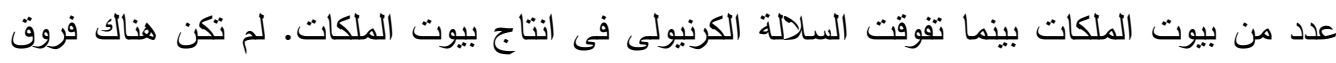

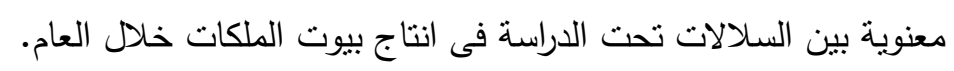
تفوقت السلالة الايطالى فى نشاط جمع حبوب اللقاح المخزونة بينما كان الهجين أول إيطالى

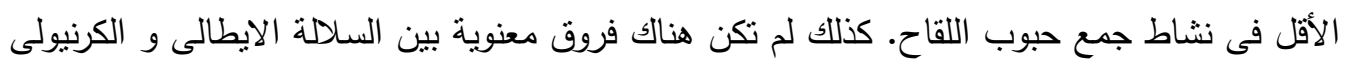
فى نشاط جمع حبوب اللقاح المخزونة. فى حين أنتجت السلالة الإيطالى و الكرنيولى أكبر كمية من الكن

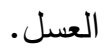

